\title{
Influence of dye structure and temperature on the adsorption of acid dyes onto polyamide 6 knitwear
}

\section{REZUMAT - ABSTRACT}

\author{
Influența structurii colorantului și a temperaturii asupra adsorbției coloranților acizi pe tricoturile \\ din poliamidă 6
}

\begin{abstract}
A fost studiată influența structurii colorantului și a temperaturii de vopsire asupra adsorbției coloranților acizi pe tricoturile din poliamidă 6 (PA 6). Au fost utilizați trei coloranți acizi cu conținut diferit de grupări sulfonice, și anume C. I. roșu acid 88, C. I. roșu acid 14 și C. I. roșu acid 18. Vopsirea a fost efectuată cu aparatul Launder-ometer la $40^{\circ} \mathrm{C} s ̦ i 60^{\circ} \mathrm{C}$, la pH 4. Probele au fost scoase din aparat la intervale diferite de timp. Rezultatele au arătat că atât structura colorantului, cât și temperatura de vopsire au afectat adsorbția coloranților acizi pe tricoturile din PA 6. Rata și cantitatea de adsorbție au crescut odată cu creșterea temperaturii de vopsire și cu scăderea numărului de grupări sulfonice din coloranți.
\end{abstract}

Cuvinte-cheie: colorant acid, poliamidă 6, vopsire, adsorbție

Influence of dye structure and temperature on the adsorption of acid dyes onto polyamide 6 knitwear

In this research, the influence of dye structure and dyeing temperature on the adsorption of acid dyes onto polyamide 6 knitwear (PA 6) was studied. Three acid dyes with different amounts of sulphonic groups, namely C. I. Acid Red 88, C. I. Acid Red 14, and C. I. Acid Red 18 were used. Dyeing was performed in a Launder-ometer apparatus at $40^{\circ} \mathrm{C}$ and $60^{\circ} \mathrm{C}$, at $\mathrm{pH}$ 4. The samples were taken out of the apparatus at different time intervals. The results showed that both dye structure and dyeing temperature affected the adsorption of acid dyes onto PA 6 knitwear. The rate and quantity of adsorption increased with an increase in dyeing temperature and a decrease in the number of sulphonic groups in dyes.

Keywords: acid dye, polyamide 6, dyeing, adsorption

\section{INTRODUCTION}

The adsorption of acid dyes onto polyamide 6 fibres is affected by a number a factors such as: dye structure, dye concentration, dyeing agents (e.g., levelling agents), liquor-to-goods ratio, dyeing temperature, dyeing time, and $\mathrm{pH}$ value of the dyebath [1-3]. In the process of dyeing, acid dyes migrate from the dyebath onto a fibre surface as a consequence of different attractive intermolecular forces between dyes and fibres. These attractive forces usually depend on both the chemical structure of dyes and the presence of functional groups on fibre surface that are mostly $\mathrm{pH}$-dependent. During dyeing, the concentration of dyes on the fibre surface increases with dyeing time, whilst that in the dyebath decreases. Equilibrium is reached at the interface fibre-dyebath, when the concentration of dyes on the fibre does not change with time. At this point the adsorption rate of dyes from the dyebath is equal to the desorption rate of dyes from the fibre surface [4]. One of the factors that affect the adsorption of dyes onto fibres is the chemical structure of dyes. The studies done so far showed that the number of sulphonic groups in acid dyes affects the adsorption onto the cationic textile substrate [5-8], to which polyamide belongs in an acidic $\mathrm{pH}$. The dyes containing more sulphonic groups are adsorbed by polyamide and wool fabrics to lesser extent in comparison to those containing fewer sulphonic groups. Studies showed that the acid dyes containing one sulphonic group exhibit good adsorption capability for a polyamide at high $\mathrm{pH}$ values, whilst the satisfactory adsorption of acid dyes with multiple sulphonic groups is obtained only at very low $\mathrm{pH}$ values [5]. The number of sulphonic groups in acid dyes also affects the overdyeing process of polyamide. Numerous studies [5-6, 8] showed that overdyeing appeared on the polyamide when acid dyes with higher affinity were used, and when dyes included a lower number of sulphonic groups in the structure. The highest overdyeing of polyamide was achieved with dyes containing one sulphonic group, followed by the dye containing two sulphonic groups, then the dye with three sulphonic groups, whilst the dye C. I. Acid Red 41 - containing four sulphonic groups - showed no trends toward overdyeing [8]. In the area of overdyeing, the acid dyes with two or three sulphonic groups are not able to form a bridge between amido groups of adjacent chains, meaning that acid dyes with a higher amount of sulphonic groups behave similarly as dyes with only one sulphonic group [5].

The purpose of this research is to investigate the influence of both the structure of acid dyes and the dyeing temperature on the adsorption of acid dyes on polyamide 6 warp knitwear in weakly acidic conditions. The dyeing was performed with three anionic acid dyes, containing different quantities of sulphonic groups, at two dyeing temperatures $\left(40^{\circ} \mathrm{C}\right.$ and $\left.60^{\circ} \mathrm{C}\right)$, and at $\mathrm{pH} 4$. It was assumed that the exhaustion of dye to polyamide 6 knitwear is affected by the dye structure, dyeing temperature, and dyeing time. 


\section{EXPERIMENTAL}

\section{Materials}

The polyamide 6 (PA 6) warp knitwear was supplied by AquafilSLO, Ljubljana, which has the following specifications: a density of 31 lines/cm, 29 columns/ $\mathrm{cm}$, and mass per square metre $72 \mathrm{~g} / \mathrm{m}^{2}$. Before dyeing, PA 6 knitwear was soaped for 30 minutes at $45-50^{\circ} \mathrm{C}$ in a solution containing $0.5 \mathrm{~g} / \mathrm{l}$ nonionic detergent (Teopon 100; Orka, Ljubljana) using a liquor-to-goods ratio of 20:1, and was thoroughly rinsed, and air-dried. Prior to dyeing, the conditioning of samples in the standard conditions (SIST EN ISO 139:2005) was carried out. The weight of each sample was $2.0 \mathrm{~g}$.

The dyes used in the research were C.I. Acid Red 88 (AR88), C.I. Acid Red 14 (AR14), and C.I. Acid Red 18 (AR18). All dyes were Sigma Aldrich products and used as received. Citric acid and disodium hydrogen phosphate were of laboratory grade and purchased from Sigma Aldrich products. The structures of acid dyes are presented in figure 1 .

\section{Dyeing}

The dyeing of PA 6 samples was performed in the Launder-ometer apparatus using a liquor-to-goods ratio $150: 1$ at $\mathrm{pH} 4$. A Mcllvain buffer consisting of citric acid and disodium hydrogen phosphate was used to prepare a buffer solution of $\mathrm{pH} 4$. Before dyeing, the $\mathrm{pH}$ of the buffered solution was measured using the MA $5740 \mathrm{pH}$-metre (Iskra, Ljubljana). The buffer solution was prepared directly before dyeing. Knitwear was dyed with $1 \%$ o.m.f dyes. Dyeing was conducted at $40^{\circ} \mathrm{C}$ and $60^{\circ} \mathrm{C}$ in two replicates. Before dyeing, the dyebath was warmed up to the dyeing temperature and the samples were introduced into the beakers. The samples were then taken out of the beakers at the following time intervals $(t): 5,10,20$, $30,45,60,90,120,150,200,240$, and 360 minutes. The dyed samples were dried on a flat surface in the open air at room temperature of $23^{\circ} \mathrm{C}$.

\section{ANALYSIS OF DYEING}

\section{Determination of the dyebath exhaustion}

The calibration curve (absorbance vs. dye concentration) of each dye was prepared in a buffered solution of $\mathrm{pH} 4$ at $25^{\circ} \mathrm{C}$, using a $1-\mathrm{cm}$ path length quartz cell housed in an UV-VIS spectrophotometer Cary 1E (Varian, Australia). From the calibration curves the concentrations of dyes in the dyebath before and after dyeing were determined at the maximum absorption wavelength $\left(\lambda_{\max }=506 \mathrm{~nm}\right.$ for AR88, $515 \mathrm{~nm}$ for AR14, and $507 \mathrm{~nm}$ for AR18). The percentage of exhaustion $(E)$, which is a function of dyeing time and temperature, was calculated using the following equation [4]:

$$
E(\%)=100 \times \frac{C_{0}-C_{d}}{C_{o}}
$$

where $C_{o}$ and $C_{d}$ are the concentrations of dyes in the dyebath before and after dyeing.

\section{Colorimetric measurements}

The reflectance value $(R)$ at the maximum absorption wavelength $\left(\lambda_{\max }\right)$ and CIELAB colour values of the dyed fabric were measured in a standard atmosphere (SIST EN ISO 139:2005) using the SF600 PLUS-CT spectrophotometer (Datacolor, Switzerland). The measurements were conducted using illuminant $D_{65}$, measuring geometry $\mathrm{d} / 8^{\circ}, 10^{\circ}$ standard observer, and a $9 \mathrm{~mm}$ aperture. An eight-layer sample was employed to avoid the transmission of light. For each dyed sample, 10 measurements were performed and a mean value was presented as a result. From the values of $R$ the Kubelka-Munk values $(K / S)$ was calculated according to equation 2 , in order to express colour strength.

$$
\frac{K}{S}=\frac{(1-R)^{2}}{2 R}
$$

where $K$ is the absorption coefficient and $S-$ the scattering coefficient for a coloured substrate at a specific wavelength. $R$ is the fractional reflectance value of the dye on the substrate at the $\lambda_{\max }$.

\section{Adsorption kinetics}

To describe the adsorption kinetics of the studied dyes a pseudo-second order model was used, based on the following differential equation:

$$
\frac{\mathrm{d} C_{e}}{\mathrm{~d} C_{t}}=k\left(C_{e}-C_{t}\right)^{2}
$$

By the integration of equation 3 for boundary conditions $t=0$ to $t=t$ and $C_{t}=0$ to $C_{t}=C_{t}$ the following equation is given:

$$
\frac{1}{\left(C_{e}-C_{t}\right)}=\frac{1}{C_{e}}+k t
$$

where $C_{e}\left(\mathrm{mg} \mathrm{g}^{-1}\right)$ is the amount of dye adsorbed on PA6 knitwear at equilibrium, $C_{t}$ - the amount of dye

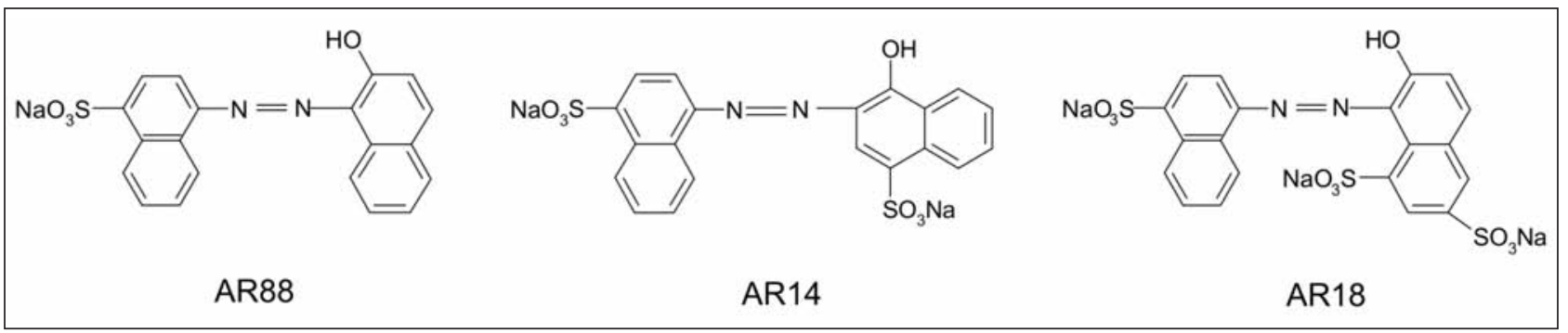

Fig. 1. Structure of the dyes used in the research 
adsorbed on PA 6 knitwear at time $t$, and $k\left(\mathrm{~g} \mathrm{mg}^{-1}\right.$ $\min ^{-1}$ ) - the adsorption rate constant.

Equation 4 can be rearranged into:

$$
\frac{t}{C_{t}}=\frac{1}{k C_{e}^{2}}+\frac{1}{C_{e}} t
$$

From the linear function of plot $t / C_{t}$ versus $t$ the adsorption parameters $k$ and $C_{e}$, and the correlation coefficient, $r^{2}$, were calculated.

\section{Determination of octanol-water partition and distribution coefficient}

The octanol-water partition coefficient, expressed in its logarithmic form $(\log P)$, is the most widely used accepted measure of lipophilicity. It refers to the partitioning of the same species of a substance between octanol and aqueous phase (equation 6).

$$
\log P_{\text {octanol/water }}=\log \left(\frac{[\text { solute }]_{\text {octanol }}}{[\text { solute }]_{\text {water }}^{\text {un-ionized }}}\right)
$$

In the case, when substances, which contain ionogenic functions, may exist as a mixture of the dissociated and undissociated forms at different $\mathrm{pH}$ values, the distribution coefficient (mostly used as $\log D$ ) is more appropriate [9]. It refers to more complex partitioning equilibria. Distribution coefficient is the ratio of the sum of the concentrations of all species of the compound in octanol to the sum of the concentrations of all species of the compound in water (equation 7).

$\log D_{\text {octanol/water }}=\log \left(\frac{[\text { solute }]_{\text {octanol }}}{[\text { solute }]_{\text {water }}^{\text {jonized }}+[\text { solute }]_{\text {water }}^{\text {neutral }}}\right)$

In the research the values of $\log P$ and $\log D$ of studied dyes was calculated by the use of MarvinSketch version 17.22, calculation module developed by ChemAxon [10], where $\log D$ was predicted from the dyes structures. The calculation is based on model, expressed in details at reference [9]. From values of $\log D$ an approximation of hydrophilic or hydrophobic performance of acid dyes can be given.

\section{RESULTS AND DISCUSSION}

The influence of acid dye structure (AR88, AR14, and AR18) on adsorption on PA 6 knitwear was spectrophotometrically evaluated by the determination of the dye concentration in the dyebath after dyeing and the colour strength $(K / S)$ of the dyed samples. In figure 2 the percentage of exhaustion $(E)$ vs. dyeing time $(t)$ is presented, whilst in figure 3 the colour strength $(K / S)$ vs. dyeing time $(t)$ is presented.

It can be seen from figure 2 that the percentage of exhaustion was strongly influenced by dyeing temperature, dyeing time, and dye structure. The values of $E$ increased with the increase of both dyeing time and dyeing temperature. For all studied dyes the higher value of $E$ was obtained at $60^{\circ} \mathrm{C}$ rather than at $40^{\circ} \mathrm{C}$. Wen et al. confirmed the same phenomenon for the dyeing of wool powders with acid dyes [10]. The percentage of exhaustion increased by prolongation of the dyeing time until equilibrium was
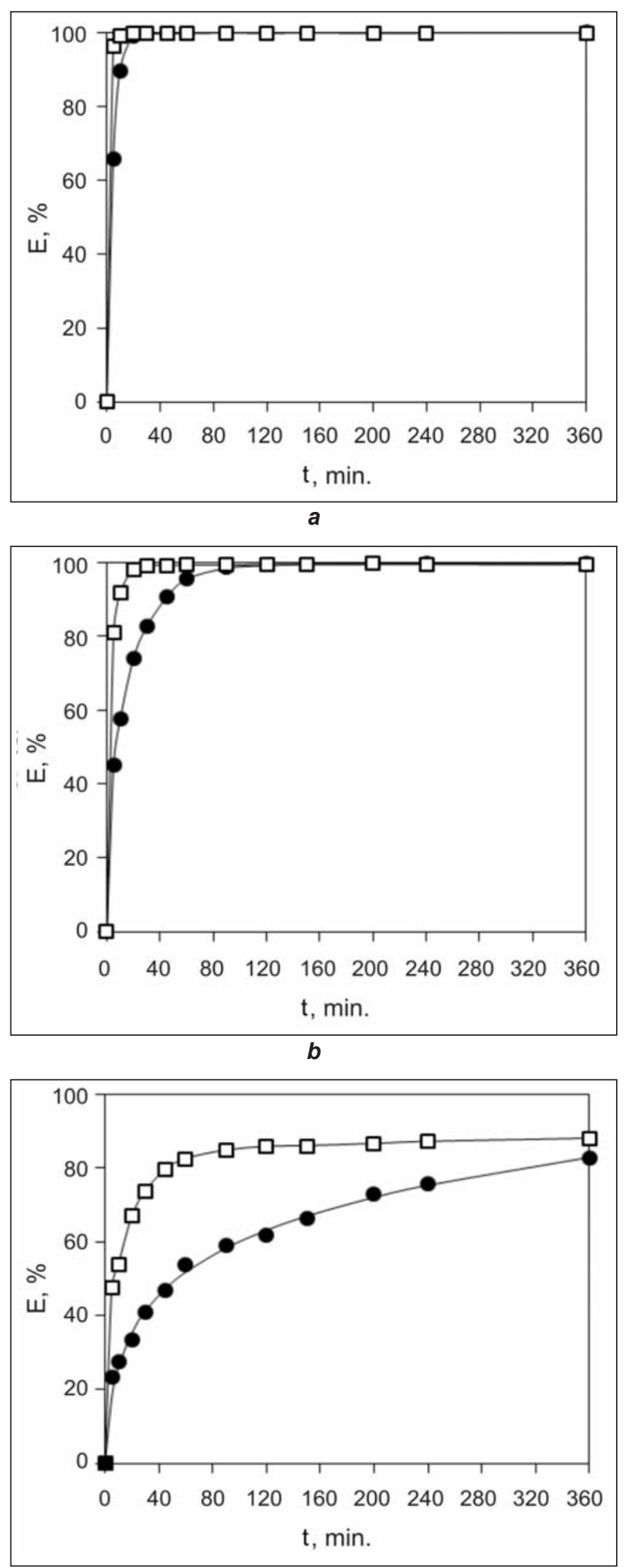

c

Fig. 2. Percentage of exhaustion as a function of dyeing time for the PA 6 knitwear dyed with AR88 (a), AR14 (b), and AR18 (c) at two temperatures. $-40^{\circ} \mathrm{C}, \square-60^{\circ} \mathrm{C}$

reached, where no change of $E$ with $t$ was noticed. Figure 2, a shows that for the dye AR88 the equilibrium was reached after 40 minutes of dyeing at $40^{\circ} \mathrm{C}$, whilst at $60^{\circ} \mathrm{C}$ the equilibrium was reached even after a shorter time, i.e. 20 minutes of dyeing. Using the dye AR14 (figure $2, b$ ) the equilibrium was reached 
after 120 minutes of dyeing in comparison to the dye AR18 (figure 2,c), where equilibrium was not reached even after 360 minutes of dyeing at $40^{\circ} \mathrm{C}$. The latter indicates that the dye uptake is strongly affected by the dye structure. Since the dyes AR88 and AR18 are structurally very similar and differ only in the number and position of sulphonic groups, it can be assumed that the number of sulphonic groups affects dye adsorption on PA 6 knitwear. Among the studied dyes, the dye AR18 has the highest number of sulphonic groups. It contains three sulphonic groups, followed by the dye AR14 with two, whilst the dye AR88 contains only one sulphonic group. The latest discoveries show that the solubility of dyes in an aqueous medium increases along with an increased in the number of sulphonic groups in the dye molecule, whilst the substantivity of dyes decreases at a given value of $\mathrm{pH}$ [11]. This is confirmed by the results presented in this paper (among the studied dyes, dye AR18 is more soluble in water than dye AR88). The binding of acid dyes to PA 6 involves different intermolecular interactions and forces, including electrostatic interactions between the anionic sulphonic group of dye $\left(-\mathrm{SO}_{3}^{-}\right)$in dyes and the protonated terminal amino groups $\left(-\mathrm{NH}_{3}^{+}\right)$in PA 6 , hydrogen bonding, van der Waals forces, and hydrophobic interactions. The latter plays an important role on the uptake of dyes by fibres and the wet fastness of dyes on fibre [2].

The comparison of the $E$ values for the studied dyes AR88, AR14, and AR18 (figure 2) showed that the dye AR88 exhausted on PA 6 knitwear to the greatest extent, followed by the dye AR14, whilst the dye AR18 showed the smallest percentage of exhaustion. It should be emphasised that the hydrophobic/ hydrophilic ratio of AR88 molecule in comparison with those of the dyes AR14 and AR18 is more on the hydrophobic side. The values of computational determination of $\log P$ and $\log D$ show that the $\log P$ for studied dyes are 3.02 (AR88), -0.44 (AR14), and -3.91 (AR18) when dyes are in ionic form, and 5.28 (AR88), 4.06 (AR14), and 2.88 (AR18) when dyes are in non-ionic form, respectively. Values of $\log D$, which are $\mathrm{pH}$ dependant, are 2.86 (AR88), -0.34 (AR14), and -3.53 (AR18) at $\mathrm{pH}$ 4. This confirms, that the hydrophilicity of dyes decreased in the following order AR88<AR14<AR18, and vice versa the hydrophobicity of dyes increases in the following order AR88>AR14>AR18. Thus, it can be concluded, that the dyes with the higher number of sulphonic groups tend to stay in aqueous phase, i.e. the dyebath at the studied $\mathrm{pH}$ value of the dyebath. In contrast to the dyes AR14 and AR18, the dye AR88, which is the most hydrophobic among the studied dyes, tends to migrate to the fibre surface. The latter is understandable, since water molecules do not form attractive intermolecular interactions with the hydrophobic part of the dye molecule, but need to rearrange themselves around the hydrophobic part of the dissolved dye. Thus, it can be concluded that

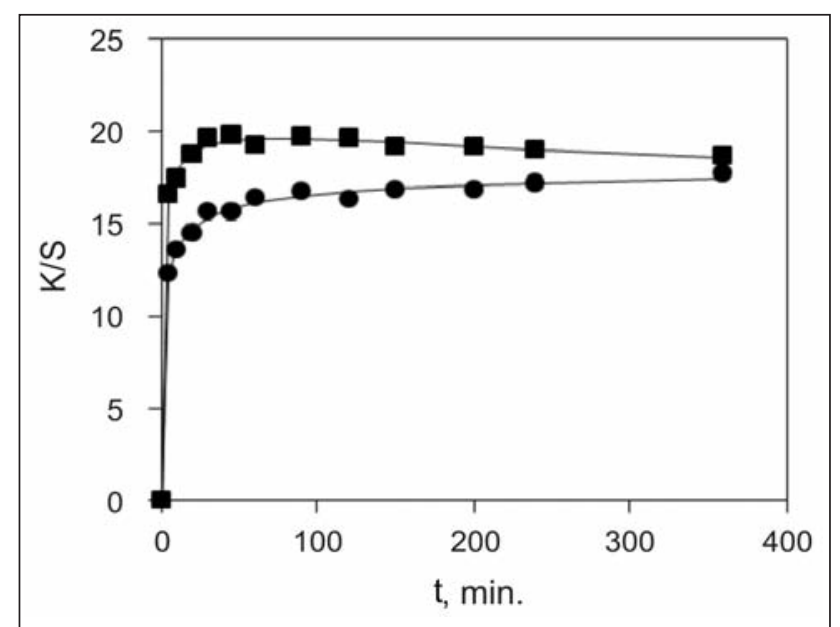

a
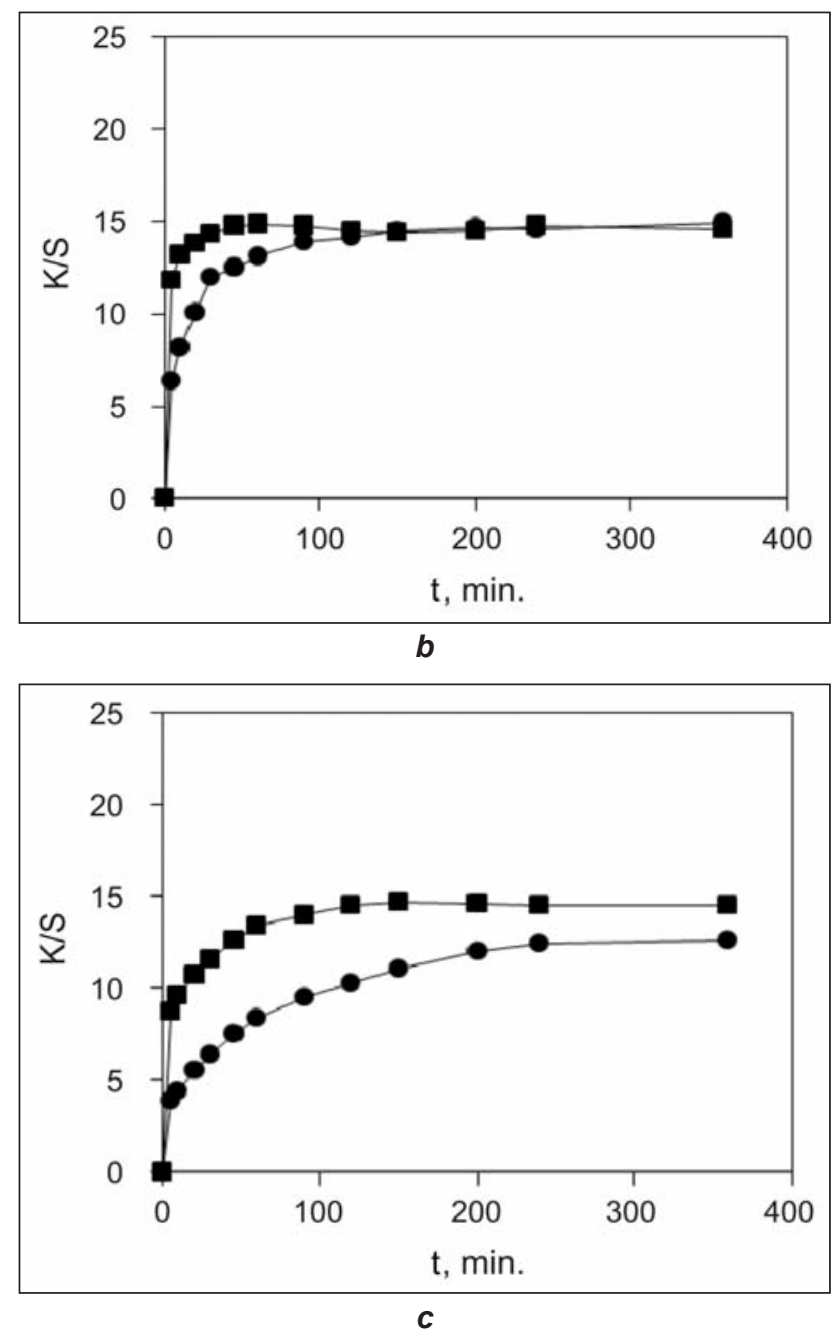

Fig. 3. Colour strength as a function of dyeing for the PA 6 knitwear dyed with AR88 (a), AR14 (b), AR18 (c) at two temperatures. $-40^{\circ} \mathrm{C}, \square-60^{\circ} \mathrm{C}$

when the dye AR88 migrates to the fibre surface more willingly, this influences the energy stability of the system.

The colour strength as a function of time, illustrated in figure 3, was influenced by dyeing time, dyeing temperature, and dye structure, similarly as the percentage of dye exhaustion. The values of $\mathrm{K} / \mathrm{S}$ increased with the increase of both the percentage of exhaustion and the dyeing temperature. 


\begin{tabular}{|c|c|c|c|c|}
\hline \multicolumn{5}{|c|}{ PARAMETERS OF ADSORPTION KINETICS FOR } \\
STUDIED DYES \\
\hline Dye & $\mathbf{T}\left({ }^{\circ} \mathrm{C}\right)$ & $\mathbf{C}_{\mathbf{e}}\left(\mathrm{mg} \cdot \mathrm{g}^{-1}\right)$ & $\mathbf{k}\left(\mathrm{g} \cdot \mathrm{mg}^{-1} \cdot \mathrm{min}^{-1}\right)$ & $\mathbf{r}^{2}$ \\
\hline AR88 & 40 & 9.82 & 0.16 & 1 \\
\hline & 60 & 11.47 & 0.80 & 1 \\
\hline AR14 & 40 & 9.26 & 0.02 & 0.9997 \\
\hline & 60 & 9.04 & 0.24 & 1 \\
\hline AR18 & 40 & 8.85 & 0.003 & 0.9903 \\
\hline & 60 & 9.04 & 0.02 & 1 \\
\hline
\end{tabular}
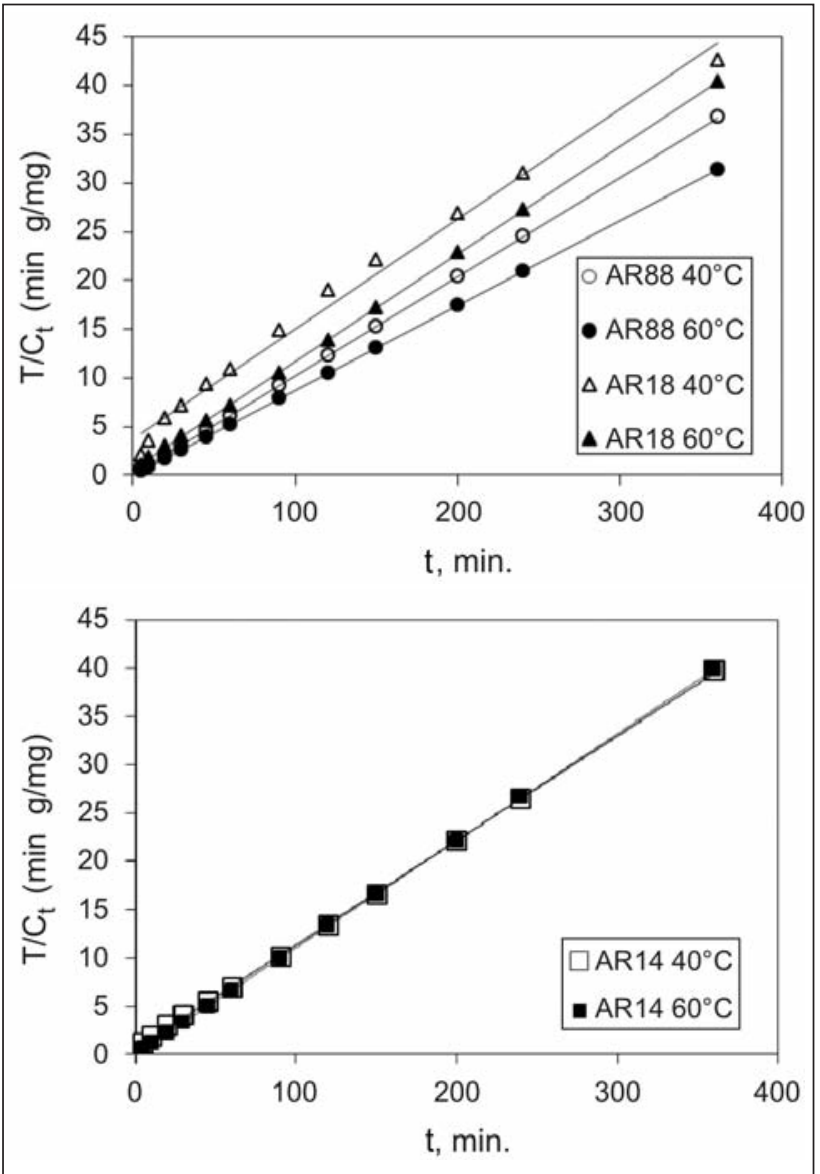

Fig. 4. Plots of $t / c_{t}$ versus $t$ of studied dyes at two dyeing temperatures

The results of adsorption kinetics are presented in table 1 and figure 4.

Linear plots of $t / c_{t}$ versus $t$ (figure 4 ) show the suitability of pseudo-second order rate equation for the AR88, AR14, and AR18 at two dyeing temperatures. The calculated adsorption rate constant $(k)$ confirms that the rate of adsorption decreases with the increase of both number of sulphonic groups in the dye molecule and dyeing temperature. The concentration of dye adsorbed at equilibrium $\left(\mathrm{c}_{e}\right)$ is the highest in the case of AR88, and the lowest in the case of AR18, irrespective of the dyeing temperature. The results of spectrophotometric measurements of dyed samples are presented in figure 5 .
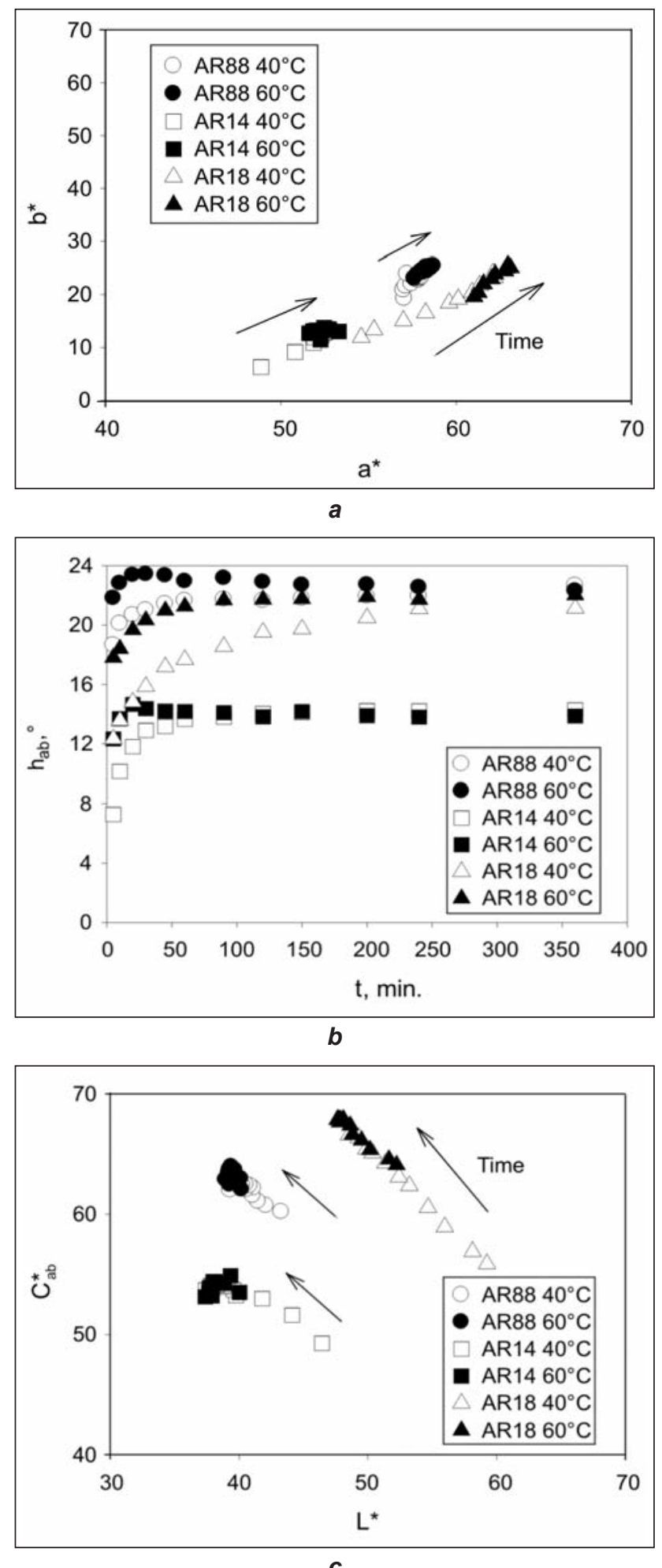

Fig. 5. Changes in the colour parameters of the PA6 knitwear in the process of dyeing: (a) $a^{*}$ vs. $b^{*}$, (b) $h_{a b}$ vs. $t,(\mathrm{c}) C^{*}{ }_{a b}$ vs. $L^{*}$

From figure $5, a$ it can be seen that both values $a^{*}$ and $b^{*}$ are positive, and increased with dyeing time irrespective of selected dye. This indicates that the knitwear becomes redder and less blue by prolonging the dyeing time. At the dyeing temperature of $60^{\circ} \mathrm{C}$, samples become even redder and less blue. PA 6 knitwear, dyed with AR18 has the highest values of $a^{*}$, followed by PA6 dyed with AR88, whilst PA6 knitwear, dyed with AR14 are less red than knitwear, 
dyed with the other two dyes. From figure 5, a it can be also seen that the values of $a^{*}$ are more grouped at the dyeing temperature $60^{\circ} \mathrm{C}$, and more scattered at the dyeing temperature $40^{\circ} \mathrm{C}$ where a progressive increase of $a^{*}$ is noticed for PA6 samples, dyed with AR14 and AR18. Also, for the PA6 sample, dyed with AR88, a very sudden increase of $a^{*}$ is noticed. At $60^{\circ} \mathrm{C}$, the values of $a^{*}$ are less dependent on increase in dyeing time. At equilibrium ( $t=360 \mathrm{~min}$ ), the values of $a^{*}$ and $b^{*}$ are almost equal for the individual dye, irrespective of dyeing temperature. The values of $h_{a b}$ (figure $5, b$ ) increase with the increasing of both dyeing time and dyeing temperature. The highest value of $h_{a b}$ is obtained on samples dyed with AR88, followed by AR18, whilst samples, dyed with AR14 have the lowest value of $h_{a b}$. At a shorter dyeing time of up to 60 minutes, a very dramatic increase of $h_{a b}$ is noticed, but from 100 minutes of dyeing till 360 minutes almost no change in $h_{a b}$ values is detected for the selected dyed sample. From figure 5, $c$ it can be seen that the CIE lightness $\left(L^{*}\right)$ decreased with the increase of both dyeing temperature and time for all studied dyes, indicating that the samples become darker during the dyeing process. At $40^{\circ} \mathrm{C}$, a more progressive decrease of $L^{*}$ is noticed for samples dyed with AR18 and AR14 than for samples dyed with AR88, whilst at $60^{\circ} \mathrm{C}$ the stepwise decrease of $L^{*}$ with the increase of dyeing time is less pronounced, especially in samples, dyed with AR88 and AR14. This suggests that the adsorption of dye AR88 onto PA 6 knitwear occurs faster in comparison with dyes AR14 and AR18. Since chroma $\left(C^{*}{ }_{a b}\right)$ is derived from values $a^{*}$ and $b^{*}$, its increase with the increase of $T$ and $t$ of dyeing is expected. Thus, the colour of PA 6 samples becomes more saturated.

\section{CONCLUSIONS}

According to the obtained results, the following can be concluded:

- A higher percentage of exhaustion of studied acid dyes is obtained at $60^{\circ} \mathrm{C}$ than at $40^{\circ} \mathrm{C}$.

- The exhaustion of studied acid dyes onto PA 6 knitwear increases with the increasing dyeing time until the equilibrium is reached, at which no changes of exhaustion are noticed. At higher dyeing temperatures the exhaustion is reached in a shorter time.

- At a given pH value of the dyebath, the acid dye with the higher number of sulphonic groups in its structure exhausts on PA 6 knitwear to a lesser extent than that with a lower number of sulphonic groups, irrespective of dyeing temperature and dyeing time.

\section{ACKNOWLEDGEMENTS}

This work was financially supported by the Slovenian Research Agency (Programme P2-0213 Textiles and Ecology).

\section{BIBLIOGRAPHY}

[1] Burkinshaw, S.M. Chemical principals of synthetic fibre dyeing, In: $1^{\text {st }}$ edition, Blackie Academic \& Professional, Glasgow, 1995, pp. 77-156.

[2] Synthetic fibre dyeing, Edited by C. Hawkyard, Society of Dyers and Colourists, Bradford, 2004, pp. 82-120.

[3] Suganuma, K. The relation between the number of sulphonic groups in acid dyes and the yield stress of dyed nylon monofilament, In: Text. Res. J., 51, nr. 10, 1981, p. 626.

[4] The theory of coloration of textiles, Edited by A. Johnson, 2nd edition, Society of Dyers and Colourists, Bradford, 1989 , p. 256.

[5] Atherton, E., Downey, D.A., Peters, R.H. Studies of the dyeing of nylon with acid dyes: Part I: Measurement of affinity and the mechanism of dyeing, In: Text. Res. J., 25, nr. 12, 1955, p. 977.

[6] Naebe, M., Cookson, P.G., Rippon, J., Brady, R.P., Wang, X. Effects of plasma treatment of wool on the uptake of sulfonated dyes with different hydrophobic properties, In: Text. Res. J., 80, nr. 4, 2010, p. 312

[7] Lewis, D.M. Dyestuff-fibre interactions, In: Rev. Prog. Color, 28, nr. 1, 1998, p. 12.

[8] Viallier, P., Jordan, C. Nylon 6.6 dyeing behaviour for fibres of different levels of fineness, In: Color. Technol., 117, nr. 1, 2001, p. 30.

[9] Csizmadia, F., Tsantili-Kakoulidou, A., Panderi, I., Darvas, F. Prediction of distribution coefficient from structure. 1. Estimation method, In: J. Pharm. Sci., 86, nr. 7, 1997, p. 865.

[10] MarvinSketch version 17.22, (www.chemaxon.com/products/marvin/marvinsketch/2017)

[11] Wen, G., Cookson, P.G., Liu, X., Wang, X.G., The effect of $\mathrm{pH}$ and temperature on the dye sorption of wool powders, In: J. Appl. Polym. Sci., 116, nr. 4, 2010, p. 2216.

[12] Aspland, J.R. Chapter II/Part 1: Anionic dyes and their application to ionic fibers: dyeing nylon with acid dyes, In: Text. Chem. Color., 25, nr. 4, 1993, p. 19.

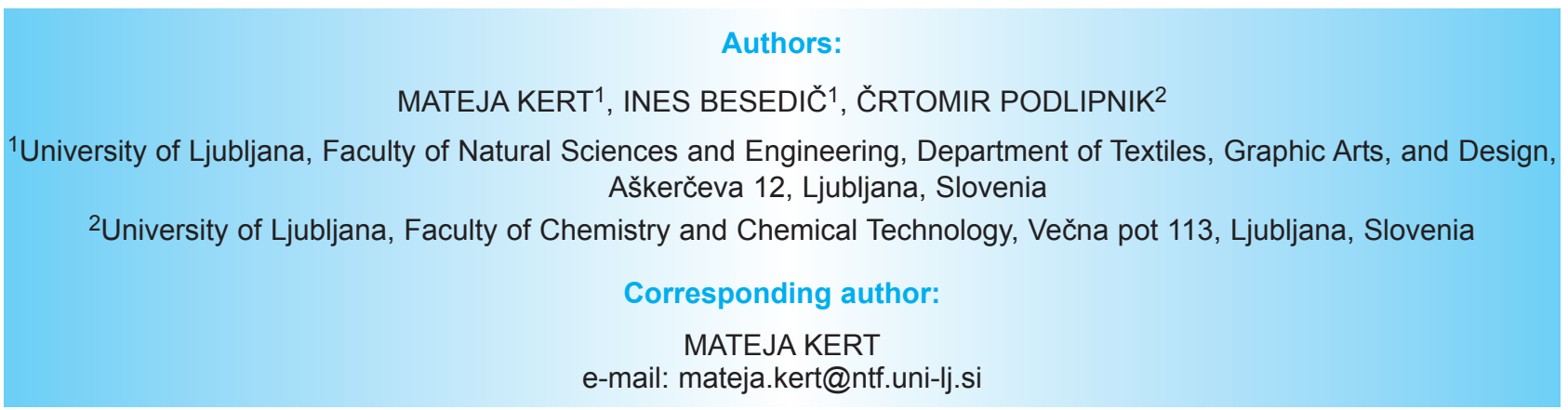

